\title{
Erosive Arthropathy in systemic sclerosis
} Fadoua Allali*1,2, Latifa Tahiri1 ${ }^{1}$ Adil Senjari1, Redouane Abouqal ${ }^{2}$ and Najia Hajjaj-Hassouni ${ }^{1,2}$

\author{
Address: ${ }^{1}$ Rheumatology department, El Ayachi University-Hospital, Sale, Morocco and ${ }^{2}$ Laboratory of Biostatistic, Clinical Research and \\ Epidemiology. LBRCE. Faculty of Medecine and pharmacy, Rabat, Morocco \\ Email: Fadoua Allali* - fadouaallali@yahoo.fr; Latifa Tahiri - latifatahiri@yahoo.fr; Adil Senjari - senjariiadil@yahoo.fr; \\ Redouane Abouqal - abouqal@invivo.edu; Najia Hajjaj-Hassouni -nhh5@hotmail.com \\ * Corresponding author
}

Published: 22 September 2007

BMC Public Health 2007, 7:260 doi:10.1 I86/ | 47/-2458-7-260
Received: 6 December 2006

Accepted: 22 September 2007

This article is available from: http://www.biomedcentral.com/I47/-2458/7/260

(c) 2007 Allali et al; licensee BioMed Central Ltd.

This is an Open Access article distributed under the terms of the Creative Commons Attribution License (http://creativecommons.org/licenses/by/2.0), which permits unrestricted use, distribution, and reproduction in any medium, provided the original work is properly cited.

\begin{abstract}
Background: To determine radiological features of arthropathy in systemic sclerosis patients with polyarthritis.

Results: Forty one women and 5 men were included in this study. The mean age was $4|+| 4,2$ years, the mean duration of disease was 10,5+ 6,5 years. Thirty seven patients $(80 \%)$ had radiological abnormalities including joint space narrowing (37\%) and erosions (43\%). At presentation, the prevalence of radiological foot abnormalities was lower than that of hands (26\% vs $79 \%, p<0,001)$. There was no significant difference between patients with $(n=24)$ and without erosive arthropathy (Joint space narrowing and/or erosion) $(n=22)$ in terms of cutaneous subtype, organ involvement, calcinosis presence of rheumatoid factor, ANA, Anti-topoisomerase antibodies.
\end{abstract}

Conclusion: This study showed an high frequency of erosive arthropathy in our morroccan SSc patients with clinical synovitis.

\section{Background}

Systemic sclerosis (SSc) is a connective tissue disease characterized by vascular involvement and fibrotic changes in the skin and internal organs. Joint symptoms have been noted in 12 to $66 \%$ of patients at the time of diagnosis and in 24 to $97 \%$ of patients at some time during the course of their illness [1]. Many radiological changes in the joints of SSc patients have been identified but erosive arthropathy is considered uncommon. The aim of this study was to assess radiological features of SSc patients with polyarthritis.

\section{Methods}

Clinical records of 60 SSc patients fulfilled the American college of rheumatology classification criteria [2], admitted to rheumatology department between 1981 and 2007 were reviewed. We included only patients with 4 or more clinical synovitis (joint swelling and/or increase in warmth). In all patients, we assessed at presentation cutaneous SSc subtype as defined by Leroy et al [3] (limited disease when skin involvement was distal to the elbow/ knees, diffuse disease when the trunk was involved), disease duration calculated from the first symptom attributable to SSc and visceral involvement defined by the following means: heart (clinical examination, electrocardiogram and if necessary echocardiography), lung (dysp- 
nea, pulmonoray function test, chest radiograph and if necessary computed tomography), kidney (urine analysis, BUN, and serum creatinine level), gastrointestinal tract (dysphagia, oesophageal manometry). The serological status of the patients for rheumatoid factor was performed by waaler rose test and latex agglutination test (cut-off level 1/40), antinuclear antibodies (ANA) was determined by indirect immunofluorescent technique on HEp-2 cells (cut-off level : 1/40), and anti DNA topoisomerase I antibodies (Anti-Scl 70) by enzyme-linked immunosorbent assay (cut-off level, $20 \mathrm{EU} / \mathrm{ml}$ ). Radiographs of hands and feet at presentation, were read by 2 independent observers. The interobserver coefficient of variability was 0,1 . Three radiological patterns of abnormalities of joints (erosion: interruption of the cortical surface; space narrowing: focal or diffuse joint narrowing), bone (radiological demineralisation: juxta-articular or generalised osteoporosis; bone resorption), and soft tissue (calcifications) were assessed.

Statistical analysis was carried out with the student's test for continuous data and chi square test for categorical data. Multiple logistic regression was used to analyse predictor variables as age, disease duration and erythrocyte sedimentation rate (ESR). Differences were considered significant when $\mathrm{p}<0,05$

\section{Results}

At presentation, 46 out of 60 SSc patients had 4 or more synovitis and were included in the study. Most of SSC patients were women (female/male ratio 8,2 ) with a mean age of $41 \pm 14,2$ (SD) years (median, 38.5 years) and a disease duration of $10,5 \pm 6,5$ years (median, 10 years). There were 16 cases $(35 \%)$ with limited scleroderma and 30 cases $(65 \%)$ with diffuse scleroderma. The prevalence of the different organs and systems involved were as follows: Lung: 57\%, Gastro-intestinal tract: $37 \%$, heart: $17 \%$, kidney: $4 \%$. Inactive digital ulcers were seen in $15 \%$ of cases (see table 1).

Twelve patients had overlap syndromes: rheumatoid arthritis, 2 cases; systemic lupus erythematosus, 3 cases, polymyositis, 3 cases, sjögren syndrome, 4 cases.

For the serological status of the patients, SSc patients were ANA positive in $62 \%$, antitopoisomerase I antibodies were positive in $33 \%$. Rheumatoid factor was positive in $31 \%$. when we compared the age $(43,3 \pm 14,1$ vs $39,8 \pm$ $14,3 ; \mathrm{p}=0,4)$ and disease duration $(11,2 \pm 7,3$ versus 9,1 $\pm 4,6 ; \mathrm{p}=0,2$ ) of SSc patients divided in limited and diffuse subset no difference emerged.

Juxtaarticular demineralization was detected in 17 patients $(37 \%)$, distal phalange resorption in 8 patients $(18 \%)$ and extra articular calcifications in 5 patients
Table I: Characteristics of systemic sclerosis (SSc) patients

\begin{tabular}{ll}
\hline Characteristics of patients & SSc patients \\
\hline $\begin{array}{l}\text { Sex: female/male } \\
\text { Mean age (years) }\end{array}$ & $41 / 5$ \\
$\begin{array}{l}\text { Mean duration of disease } \\
\text { (years) }\end{array}$ & $41 \pm 14,5 \pm 6,5$ \\
SSc subtype & \\
$\quad$ Diffuse systemic sclerosis & $30(65 \%)$ \\
$\quad$ Limited systemic sclerosis & $16(35 \%)$ \\
$\begin{array}{l}\text { Peripheral vascular (inactive } \\
\text { Digital ulcers) }\end{array}$ & $7(15 \%)$ \\
Organ involvement & \\
$\quad$ Lung involvment & $25(57 \%)$ \\
$\quad$ Gastro-intestinal involvement & $17(37 \%)$ \\
$\quad$ Heart involvement & $8(17 \%)$ \\
$\quad$ Kidney involvement & $2(4,3 \%)$ \\
Positive rheumatoid factor & $12(31 \%)$ \\
Positive antinuclear & $24(62 \%)$ \\
antibodies & \\
Antitopoisomerase I & $15(33 \%)$ \\
\hline
\end{tabular}

Values are presented as mean \pm SD and $n(\%)$

SSc: systemic sclerosis

(12\%). Radiological changes seen in our SSc patients are summarized in the table 2 . The more prevalent radiological patterns of SSc patients are illustrated in figures 1, 2, 3, 4.

At presentation, the prevalence of radiological foot abnormalities was lower than that of hands $(26 \%$ vs $79 \%$, p < $0,001)$, whereas no significant difference was detected in the prevalence of joint space narrowing $(5 \%$ of the feet vs $33 \%$ of the hands; $\mathrm{p}=0.3)$, erosion $(12 \%$ of the feet ver-



Figure I

X-ray of hands showing. - Erosion of the fourth and the fifth proximal inter phalangeal joint on the left hand. - Terminal phalangeal tuft resorption (arrow). 
Table 2: Radiological abnormalities of the hands, wrists and feet in systemic sclerosis (SSc) patients

\begin{tabular}{ll}
\hline Radiological abnormalities & Systemic patients $n=46$ \\
\hline $\begin{array}{l}\text { Radiological abnormalities } \\
\text { in the hand }\end{array}$ & \\
Bone demineralization & $33 \%$ \\
Joint space narrowing & $15(33 \%)$ \\
MCP & 3 \\
PIP & 11 \\
DIP & 2 \\
Radiocarpal & 7 \\
Joint erosions & $14(31 \%)$ \\
MCP & 4 \\
PIP & 10 \\
DIP & 1 \\
Radiocarpal & 7 \\
Ulnar styloid erosions & $\mathrm{I}(2 \%)$ \\
Radiological abnormalities & \\
in the foot & \\
Bone demineralization & $5 \%$ \\
Joint space narrowing & $2(5 \%)$ \\
MTP & $\mathrm{I}$ \\
Ankle & $\mathrm{I}$ \\
Joint erosion & $5(12 \%)$ \\
MTP & 3 \\
Talo-navicular joint & 2 \\
Terminal phalangeal tuft & $8(18 \%)$ \\
resorption & $5(12 \%)$ \\
Calcinosis & \\
\hline
\end{tabular}

Values are $n(\%)$

DIP: distal interphalangeal joint, MCP: metacarpophalangeal joint,

PIP: proximal interphalangeal joint. MTP: metatarsophalangeal joint

sus $31 \%$ of the hand; $\mathrm{p}=0.18)$ and bone demineralization ( $5 \%$ of the feet versus $33 \%$ of the hands; $p=0,29)$.

We found no significant difference between patients with $(\mathrm{n}=24)$ and without erosive arthropathy (Joint space narrowing and/or erosion) $(n=22)$ in terms of cutaneous subtype, organ involvement, calcinosis, presence of rheumatoid factor, ANA, Anti-topoisomerase antibodies (see table 3). In multiple logistic regression, age of patients >

Table 4: Correlation between some clinical patients characteristics and erosive changes in systemic sclerosis patients

\begin{tabular}{|c|c|c|c|}
\hline Variable & $\begin{array}{l}\text { Odds Ratio } \\
\text { (OR) }\end{array}$ & $\begin{array}{l}95 \% \\
\text { Confidence } \\
\text { interval }\end{array}$ & P* \\
\hline Age $>38$ years & $\mathrm{I}, 15$ & $0,33-3,9$ & 0,8 \\
\hline $\begin{array}{l}\text { Disease } \\
\text { duration > } 10 \\
\text { years }\end{array}$ & 2,1 & $0,6 I-7,3$ & 0,2 \\
\hline $\mathrm{ESR}>30 \mathrm{~mm}$ & 3 & $0,8-11,8$ & 0,1 \\
\hline
\end{tabular}

* Multiple logistic regression

ESR: erythrocyte sedimentation rate
Table 3: Comparison between clinical and serological features of SSc patients with and without joint erosions

\begin{tabular}{|c|c|c|c|}
\hline & $\begin{array}{c}\text { Erosive } \\
\text { arthropathy } \mathrm{N} \\
=24(\%)\end{array}$ & $\begin{array}{l}\text { Non erosive } \\
\text { arthropathy N } \\
=22(\%)\end{array}$ & $\mathrm{P}^{*}$ \\
\hline \multicolumn{4}{|l|}{ SSc subtype } \\
\hline Diffuse SSc & 77,5 & 51,8 & 0,2 \\
\hline Limited SSc & 22,5 & 48,2 & 0,3 \\
\hline Digital ulcers & 13 & 18 & 0,5 \\
\hline Calcinosis & 4 & 18 & 0,1 \\
\hline \multicolumn{4}{|l|}{$\begin{array}{l}\text { Organ } \\
\text { involvement }\end{array}$} \\
\hline $\begin{array}{l}\text { Lung } \\
\text { disease }\end{array}$ & 58 & 50 & 0,5 \\
\hline $\begin{array}{l}\text { Kidney } \\
\text { involvement }\end{array}$ & 4 & 4 & 1 \\
\hline $\begin{array}{l}\text { Heart } \\
\text { involvement }\end{array}$ & 21 & 14 & 0,5 \\
\hline $\begin{array}{l}\text { Gastro- } \\
\text { intestinal } \\
\text { involvement }\end{array}$ & 32 & 42 & 0,9 \\
\hline $\begin{array}{l}\text { Associated } \\
\text { connectivitis }\end{array}$ & 21 & 30 & 0,4 \\
\hline RA & 8 & 0 & 0,1 \\
\hline SLE & 4 & 9 & 0,6 \\
\hline $\begin{array}{l}\text { Sjögren's } \\
\text { Syndrome }\end{array}$ & 0 & 18 & 0,08 \\
\hline $\begin{array}{l}\text { Polymyositi } \\
\text { s }\end{array}$ & 8 & 5 & 0,4 \\
\hline $\begin{array}{l}\text { Positive } \\
\text { rheumatoid } \\
\text { factor }\end{array}$ & 33 & 18 & 0,2 \\
\hline $\begin{array}{l}\text { Positive } \\
\text { antinuclear } \\
\text { antibodies }\end{array}$ & 46 & 60 & 0,9 \\
\hline $\begin{array}{l}\text { Anti } \\
\text { topoisomera } \\
\text { se I antibody }\end{array}$ & 4 & 5 & 0,9 \\
\hline
\end{tabular}

38 years, disease duration longer than 10 years and ESR levels $>30 \mathrm{~mm} / \mathrm{h}$ at presentation were risk factors but not significant association with erosions emerged (see table 4)

\section{Discussion}

This study analyzed SSc patients with polyarthritis that has been observed in 46 out of 60 cases. This result is in agreement with Misra et al [4] who had documented clinical synovitis and joint inflammation with imaging techniques in $88 \%$ and $91 \%$, respectively, of their SSc patients with a current or past history of articular symptoms. Erosive arthropathy was seen in $24 / 46$ cases, is in agreement with prevalence of other reports $[1,5,6]$. The erosions were frequently atypical of rheumatoid arthritis, tended to be small and discrete, reflecting the relatively non invasive nature of the synovium in SSc. Histological studies have shown mild proliferation and fibrosis without pannus 


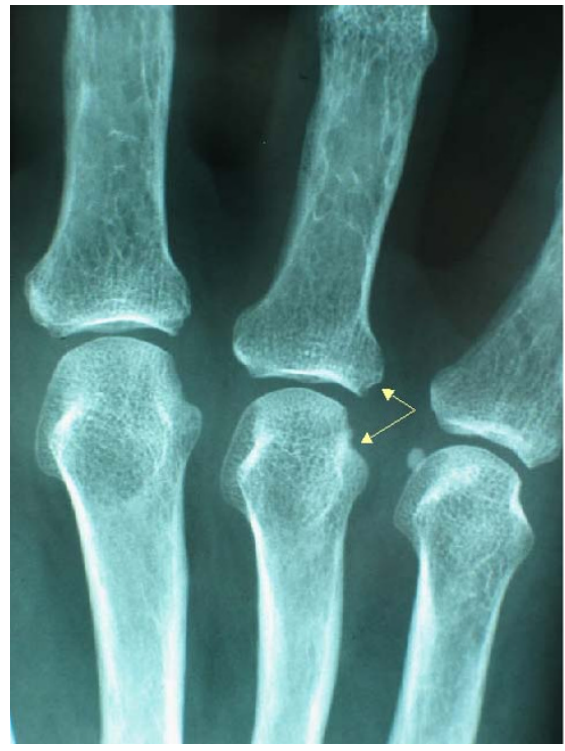

\section{Figure 2}

X-ray of hand showing: a small and discrete lesion in the fourth metacarpo-phalangeal joint similar to early rheumatoïd arthritis.

formation [7]. The cause of erosions in SSc remains unclear and has been hypotesized a role of traction of tendons on demineralised bone or ischemic bone resorption $[8,9]$. Rabinowitz et al [10] reviewed the hand and wrist $\mathrm{x}-$

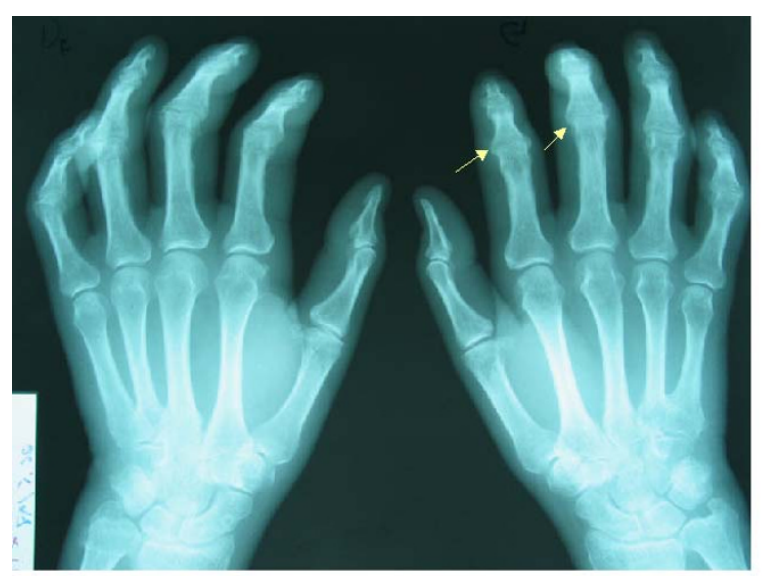

\section{Figure 3}

X-ray of hands showing a joint space narrowing in the proximal inter phalangeal joint similar to erosive osteoarthritis.

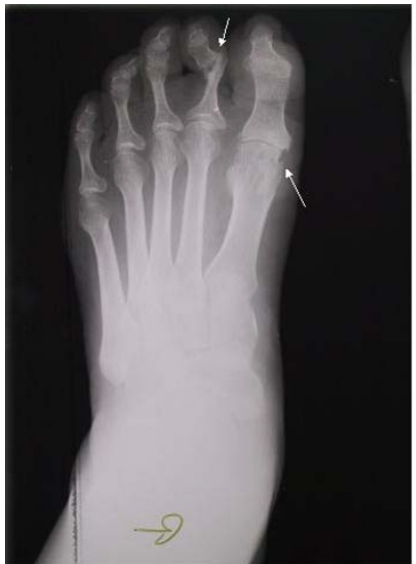

Figure 4

X-ray of a left foot. Erosive lesion in the first metatarsophalangeal joint, and subluxation and erosion of the second proximal inter phalangeal joint similar to psoriatic arthritis.

rays of 24 patients with scleroderma. All had mild arthralgia or arthritis, and bone erosions were seen in 13 patients. The x-rays of 7 patients showed many features in common with rheumatoid arthritis.

A marked erosive lesions resembling rheumatoid arthritis may be observed in SSc patients [10]. In our study, the diagnosis of scleroderma in the two cases who had changes resembling those seen in rheumatoid arthritis was not in doubt. They had a proximal scleroderma changes considered to be the major manifestation of this disorder. An overlap syndrome can not be excluded in those cases. One third of our patients had positive test for rheumatoid factor. This may occur in $30 \%$ of patients with scleroderma. Clark et al [11] found a correlation between inflammatory synovial biopsy appearances and the presence of rheumatoid factor in the serum or synovial fluid. Kellgren and Ball [12] believed that high titres of rheumatoid factor tended to occur in patients with proeminent articular features. However this was not confirmed by Rodnan [13] in his study of 29 patients. Recently Ingegnoli et al [14] found in 75 SSc patients a statistically significant association between the positivity of anti cyclic citrullinated peptide antibodies (anti CCP) and the presence of arthritis and marginal erosions. This may help to define the diagnosis of overlap syndrome SSc/RA and to facilitate diagnosis and appropriate treatment. Two thirds of our patients had ANA positivity. Prevalence of ANA in our series is lower than that reported in European studies $[6,15]$, whereas is in agreement with a recent a Moroccan study [16]. We hypothesized that this may be due to etnic variability. 
In our study, the more frequent changes were joint space narrowing in PIP, that may be due to deformities of the fingers caused by soft tissue contractures. Instead the joint space narrowing of DIP joints were uncommon in contrast with Avouac et al [17] who described a higher frequency of changes. Many of those cases were associated with erosive changes and a radiological picture compatible with erosive osteoarthritis. However, the DIP lesions appear to be both deeper and more destructive than the usual picture of erosive osteoarthritis. Selective erosions of the first carpo-metacarpal joint has been described in scleroderma $[9,18]$. In this study, the PIP joint and radiocarpal joint were the most common site for erosions. An interesting finding in our patients was the difference between Feet and hand radiologic abnormalities that in agreement with La Montagna findings in his longitudinal study of 100 patients [6] confirms that the foot involvement is less frequent. Hand changes is generally observed at disease onset and remained nearly unchanged over time, foot changes began later and worsened with ongoing disease [6]. This contrast with rheumatoid arthritis patients in whom radiologic features occur earlier in the feet than in the hands, although the rate of damage progress similarly.

In Previous reported data, destructive arthropathy was associated to high $\mathrm{C}$ reactive proteine concentration $(>10$ $\mathrm{mg} / \mathrm{l}$ ) suggesting that inflammatory articular involvement may partly account for the unusual inflammatory syndrome observed in SSc patients [17]. In our study, no relation was found between the occurrence of destructive arthropathy and age, organ involvement, calcinosis, associated connectivitis, presence of rheumatoid factor and antinuclear antibodies. In the multiple logistic regression analysis, higher ESR age $>38$ years or disease duration > 10 years, were risk factors for occurrence of erosions but a not significant relationship was found, indicating that probably other factors may be considered.

Our study has many limitations; it was a retrospective study and analyzed a small number of patients. Large studies including patients with scleroderma and erosive arthropathy are required to confirm our results.

\section{Conclusion}

We documented a high frequency of clinical synovitis in our SSc patients, and a relatively low prevalence of ANA in Moroccan SSc patients. Other studies on SSc patients with arthropathy are needed to confirm our results.

\section{Competing interests}

The author(s) declare that they have no competing interests.

\section{Authors' contributions}

FA and NH-H conceived the study and supervised its design, execution, and analysis and participated in the drafting and critical review of the manuscript. RA participated in the concept and design of the study, did data management and statistical analyses and participated in the drafting and critical review of the manuscript. LT and AS enrolled patients, participated in data acquisition and critical revision of the manuscript. FA wrote the paper, all authors read and approved the final manuscript.

\section{Acknowledgements}

This study was financially supported by the university Mohamed V. Souissi.

\section{References}

I. Baron M, Lee $\mathrm{P}$, Keystone E: The articular manifestations of progressive systemic sclerosis (scleroderma). Ann Rheum Dis 1982, 41 (2): 147-52.

2. Subcommittee for Scleroderma Criteria of the American Rheumatism Association Diagnostic and Therapeutic Criteria Committee: Preliminary criteria for classification of systemic sclerosis (scleroderma). Arthritis Rheum 1989, 23:581-90.

3. Le Roy EC, Black C, Fleischmajer R, Jablonska S, Kreig T, Medsger TA Jr, et al.: Scleroderma (systemic sclerosis): classification, subsets and pathogenesis. J Rheumatol 1988, I 5:202-5.

4. Misra R, Darton K, Jewkes RF, Black CM, Maini RN: Arthritis in scleroderma. BrJ Rheumatol i 995, 34(9):831-7.

5. La Montagna G, Sodano A, Capurro V, Malesci D, Valentini G: The arthropathy of systemic sclerosis: a 12 month prospective clinical and imaging study. Skeletal Radiol 2005, 34:35-4I.

6. La Montagna G, Baruffo A, Tirri R, Buono G, Valentini G: Foot involvement in systemic sclerosis: a longitudinal study of 100 patients. Semin Arthritis Rheum 2002, 3 I:248-55.

7. RODNAN GP: The nature of joint involvement in progressive systemic sclerosis (diffuse scleroderma). Ann Intern Med 1962, 56:422-439.

8. Catoggio LJ, Evison G, Harkness JAL, Madisson PJ: The arthropathy of systemic sclerosis (scleroderma); comparison with mixed connective tissue disease. Clin Exp Rheumatol 1983, I:I0I-I2.

9. Generini S, Fiori G, Moggi PA, Matucci-Cerinic M, Cagnoni M: Systemic sclerosis. In A clinical overview. Rheuma Derm Mallia and Uitto: New York; 1999:73-83.

10. Rabinowitz JG, Twersky J, Guttadauria M: Similar bone manifestations of scleroderma and rheumatoid arthritis. Radiology 1974, | 2 | :35-44.

II. Clarck JA, Winkelmann RK, Mc Duffie FC, Ward LE: Synovial tissue changes and rheumatoid factors in scleroderma. Mayo Clin Proc 1971, 46:97-103.

12. Kellgren $\mathrm{JH}$, Ball J: Clinical significance of the rheumatoid serum factor. Br Med J 1959, i:523-31.

13. Rodnan GP, Medsger TA: The rheumatic manifestations of progressive systemic sclerosis (scleroderma). Clin Ortop 1968, 8:81-93.

14. Ingegnoli F, Galbiati V, Zeni S, Meani L, Zahalkova L, Lubatti C, Soldi A, Paresce E, Murgo A, Crapanzano C, Fantini F: Use of antibodies recognizing cyclic citrullinated peptide in the differential diagnosis of joint involvement in systemic sclerosis. Clin Rheumatol 2007, 26(4):510-4.

15. Maione S, Cuomo G, Giunta A, Tanturri de Horatio L, La Montagna G, Manguso F, Alagia I, Valentini G: Echocardiographic alterations in systemic sclerosis: a longitudinal study. Semin Arthritis Rheum 2005, 34(5):721-7.

16. Admou B, Arji N, Seghrouchni F, Missoum H, El Fenniri L, Amghar S, El Aouad R: Low prevalence of anti-centromere antibodies in scleroderma in Morocco (about 272 cases). Ann Biol Clin (Paris) 2007, 65(3):291-7.

17. Avouac J, Guerini H, Wipff J, Assous N, Chevrot A, Kahan A, Allanore $Y$ : Radiological hand involvement in systemic sclerosis. Ann Rheum Dis 2006, 65:1088-92. 
18. Resnick D, Greenway G, Vint VC, Robinson CA, Piper S: Selective involvement of the first carpo-metacarpal joint in scleroderma. Am J Roeentgenol 1978, 131:283-86.

\section{Pre-publication history}

The pre-publication history for this paper can be accessed here:

http://www.biomedcentral.com/1471-2458/7/260/pre

pub

Publish with Bio Med Central and every scientist can read your work free of charge

"BioMed Central will be the most significant development for disseminating the results of biomedical research in our lifetime. " Sir Paul Nurse, Cancer Research UK

Your research papers will be:

- available free of charge to the entire biomedical community

- peer reviewed and published immediately upon acceptance

- cited in PubMed and archived on PubMed Central

- yours - you keep the copyright 